\title{
Direct Gene Quantitation by PCR Reveals Differential Accumulation of Ectopic Enzyme in Rat-1 Cells, v-fos Transformants, and Revertants
}

\author{
M. Bahman Bahramian and Helmut Zarbl
}

\begin{abstract}
Division of Toxicology, and Center for Environmental Health Sciences, Whitaker College of Health Science and Technology,
\end{abstract} Massachusetts Institute of Technology, Cambridge, Massachusetts 02139

\begin{abstract}
Valid comparisons of gene promoter activities between different cell lines, and within a cell line, critically depend on accurate measurements of the number of genes introduced into the nuclei of cells. We have developed a simple method that allows direct and accurate quantitation of transfected plasmid DNA in cultured cells. The transfected DNA present in nuclei is copurified with genomic DNA without using phenol/chloroform extractions. DNA is amplified by PCR, and the amount of transfected DNA is read directly from a standard curve. By using the procedures described in this report, we have studied the relative expression of the Escherichia coll $\beta$-galactosidase gene, driven by the wild-type Mo-MuLV LTR, in Rat-1 fibroblasts, FBJ v-fostransformed Rat-1 (1302), and a revertant of v-fos-transformant (EMS1-19) cell lines. The relative levels of expression of the transgene at $22 \mathrm{hr}$ post-transfection in these three cell lines were 1:4:1, respectively, and at $48 \mathrm{hr}$ post-transfection the respective ratios were 1:10.6:4. These results have significant implications for the use of cotransfected internal control plasmids to normalize data from transient transfection experiments to study promoter activities among different cell lines.
\end{abstract}

$\mathbf{W}$ hen using transient transfection assays to measure the effect of promoters and enhancers on gene expression, it is essential to include an internal control that will distinguish differences in the level of transcription from differences in the efficiency of transfection or in the preparation of cell extracts. This is accomplished most often by cotransfecting cells with two plasmids. The reporter plasmid carries the promoter-reporter gene construct under investigation. The internal control plasmid constitutively expresses a gene encoding another activity that can be assayed in the same cell extracts prepared for measurements of a reporter gene activity. ${ }^{(1)}$ An enzyme frequently used as internal control is Escherichia coli $\beta$-galactosidase, which is usually expressed in transfected mammalian cells from a promoter with a broad host range, the SV40 early promoter/enhancer ${ }^{(2,3)}$ or the long terminal repeat (LTR) of Rous sarcoma virus. ${ }^{(4)} \mathrm{Al}$ though extracts of most types of mammalian cells contain endogenous $\beta$-galactosidase activity, an increase in enzyme activity can usually be detected during the course of transfection. However, certain cell lines, for example, gut epithelial cells ${ }^{(1)}$ and rat fibroblast cells (this work), contain high levels of this activity, which results in difficulties with this assay.

A number of different approaches can be used to normalize the reporter gene activity to the $\beta$-galactosidase activity. For example, the amount of protein in individual extracts prepared from a series of transfected cells can be measured, and the reporter gene and $\beta$-galactosidase assays can then be carried out using a standard amount of protein in each assay. The reporter gene activity is then normalized to the $\beta$-galactosidase activity. Alternatively, the $\beta$-galactosidase activity in a constant volume of extract is measured and the reporter gene assay is then carried out with amounts of extract that contain a defined amount of $\beta$-galactosidase activity. The disadvantage of the latter method is the uncertainty about the endogenous $\beta$-galactosidase contribution, as neither the cell numbers nor the protein concentrations are known; also cell lysis efficiencies in different extracts are unknown.

Because of endogenous $\beta$-galactosidase activity, errors in cell number and protein determinations, and limitations of spectrophotometric measurements, only the increase in $\beta$-galactosidase activity from efficiently transfected cells, and after a long post-transfection incubation period (24-48 hr), can be measured with reasonable certainty.

Additional problems are encountered with the cotransfection method when the expression of a specific gene is compared in different cell lines. This is particularly true when comparing promoter activities between normal cells and tumor cells, or between undifferentiated versus differentiated cells. The intrinsic activity of the internal control promoter, the respective gene product accumulation, and the total protein per cell could be different among these different cell types.

Recently, a sensitive method for de- 
tection of $\beta$-galactosidase in transfected mammalian cells was described. ${ }^{(5)}$ Chlorophenol red $\beta$-D-galactopyranoside (CPRG), an alternative substrate for $\beta$-galactosidase, was substituted for 2-nitrophenyl- $\beta$-D-galactopyranoside (ONPG) in an optimized, automated colorimetric assay system. This method was shown to be 100-fold faster and 10-fold more sensitive than previous methods to detect $\beta$-galactosidase. A further improvement in the same report was the use of Nonidet P-40 (NP-40) in making homogeneous cell extracts, instead of the freeze-thaw procedure used previously. However, these improvements do not resolve any of the problems discussed above.

Clearly, a direct method for determination of plasmid DNA in nuclei of transfectants would be of great advantage. Hybridization methods for measurements of transfected DNA have not proved to be very quantitative, as background-to-signal ratios are often too high. Recent procedures ${ }^{(6,7)}$ for sequential extraction of RNA and DNA from the same sample are not quantitative and reproducible, and in our experience, the transfected plasmid DNA fractionates mainly with RNA rather than with genomic DNA. In this report we describe a relatively simple method for copurification of plasmid DNA with genomic DNA from the nuclei of transfected cells. This procedure does not require the use of columns or organic solvent extraction; DNA purification is quantitative, and the DNA is sufficiently clean for quantification by a PCR procedure. Transfected plasmid copy numbers can be measured directly and at any time after transfection. By using the methods described in this report, we have studied transient expression of the $\beta$-galactosidase gene, driven by wild-type Moloney murine leukemia virus long terminal repeat (Mo-MuLV LTR), in normal Rat-1 fibroblast cells, v-fos-transformed Rat-1, and a revertant of the v-fos-transformed Rat-1, at $22 \mathrm{hr}$ and $48 \mathrm{hr}$ postelectroporation.

\section{MATERIALS AND METHODS \\ Cell Culture, Cell Lines, and Transfection}

Cell culture conditions and the generation of FBJ v-fos transformed cell line 1302-4-1 and revertant EMS-1-19 have been described previously. ${ }^{(8)}$
Approximately $24 \mathrm{hr}$ prior to transfection, subconfluent cells, passaged into $10-\mathrm{cm}$ culture dishes, were fed with minimum Eagle's medium (MEM) supplemented with $10 \%$ calf serum (Flow Labs). For transient transfections, cells were grown to $\sim 70 \%$ confluence, trypsinized, pooled, pelleted, and resuspended at $10^{7}$ cells $/ 0.5 \mathrm{ml}$ in MEM plus $10 \%$ calf serum. Each $0.5 \mathrm{ml}$ of cells was combined with $10 \mu \mathrm{g}$ of plasmid DNA in a sterile tube and transferred to a sterile cuvette for electroporation. Using a BioRad electroporation apparatus, cells were subjected to a single pulse at $340 \mathrm{~V}$, capacitance $940 \mu \mathrm{F}$, at room temperature. After $\sim 5 \mathrm{~min}$, the electroporated cells were plated in MEM plus $10 \%$ calf serum at densities that allowed cells to be in log-phase growth after $48 \mathrm{hr}$ in culture.

The $\beta$-gal-transducing plasmid, BAG, ${ }^{(9)}$ which constitutively expresses $\beta$-galactosidase gene from the wild-type Mo-MuLV LTR, was used in these studies.

\section{Harvesting Cells and Nuclei from Electroporated Cells}

Cells on culture dishes were washed twice with $8 \mathrm{ml}$ of MEM plus $10 \%$ ( $\mathrm{vol} /$ vol) calf serum $12-16 \mathrm{hr}$ after electroporation. Fresh medium was added, and the cells were incubated for up to $22 \mathrm{hr}$, or as required. The plates were washed with phosphate-buffered saline (PBS). One milliliter of trypsin solution was added to each plate and agitated. After 2 min, $8 \mathrm{ml}$ of MEM plus $10 \%$ calf serum was added and the cell suspension was transferred to a $15-\mathrm{ml}$ polystyrene tube on ice. The plate was quickly rinsed with $\sim 3 \mathrm{ml}$ of PBS, and the rinse solution was added to the cell suspension. An aliquot of the cell suspension was removed for measuring cell number.

The cells were pelleted in a clinical centrifuge at $4^{\circ} \mathrm{C}$, at $1100 \mathrm{~g}$, for $2 \mathrm{~min}$. The supernatant was removed, and the pellet was resuspended in $3 \mathrm{ml}$ of icecold PBS. One half of the cell suspension was transferred to a $1.5-\mathrm{ml}$ microcentrifuge tube. The other half of the cells were left on ice for preparation of nuclei and DNA. The cells in the tube were centrifuged at $4^{\circ} \mathrm{C}$ for $20 \mathrm{sec}$, the supernatant was removed, and the pellet was used for either RNA or cell extract preparation.

The cell pellet in the $15-\mathrm{ml}$ polystyrene tube on ice was gently resuspended in $2 \mathrm{ml}$ of ice-cold lysis buffer $(10 \mathrm{~mm}$
Tris- $\mathrm{Cl}$ at $\mathrm{pH} 7.4,10 \mathrm{~mm} \mathrm{NaCl}, 3 \mathrm{~mm}$ $\mathrm{MgCl}_{2}$, and $0.5 \% \mathrm{NP}-40$, made from sterile stock solutions; ${ }^{(10)}$ incubated on ice for $5 \mathrm{~min}$, and centrifuged at $4^{\circ} \mathrm{C}, 1100 \mathrm{~g}$, for $5 \mathrm{~min}$. The supernatant contains the cytoplasmic RNA. The nuclear pellet was resuspended gently in $2 \mathrm{ml}$ of cold lysis buffer. The nuclei were pelleted for 5 min as before. The supernatant was removed, and the nuclei were resuspended in $2 \mathrm{ml}$ of lysis buffer. A drop of the final nuclei suspension was examined microscopically to ensure that the nuclei were not ruptured and cells were lysed completely. The nuclei were pelleted by centrifugation for $5 \mathrm{~min}$ at $4^{\circ} \mathrm{C}$. The supernatant was removed with a pipette tip, taking care not to disturb the nuclear pellet. The nuclei were stored at $-20^{\circ} \mathrm{C}$, until required.

\section{Purification of Genomic plus Plasmid DNA from Electroporated Cell Nuclei}

The purified nuclei from $\sim 5 \times 10^{6}$ transfected cells were resuspended in $50 \mu \mathrm{l}$ of TE (10 mM Tris-Cl, $1 \mathrm{~mm}$ EDTA at pH 8.0) and transferred to a microcentrifuge tube; $0.5 \mathrm{ml}$ of extraction buffer $(10 \mathrm{~mm}$ Tris-Cl, at pH 8.0, $0.1 \mathrm{M}$ EDTA at $\mathrm{pH} 8.0$, $0.5 \% \mathrm{SDS}$ ) and $2 \mu \mathrm{l}$ of a $10 \mathrm{mg} / \mathrm{ml}$ DNasefree pancreatic RNase stock solution were added, and the suspension was incubated at $37^{\circ} \mathrm{C}$ for $1 \mathrm{hr}$ with occasional swirling. Proteinase $\mathrm{K}$ was added to a final concentration of $100 \mu \mathrm{g} / \mathrm{ml}$ from a $20 \mathrm{mg} / \mathrm{ml}$ stock solution, and the lysate was incubated at $50^{\circ} \mathrm{C}$ for $3 \mathrm{hr}$ with occasional swirling.

After cooling to room temperature, the lysate was passed rapidly, 12 times, through an 18-gauge hypodermic needle, to shear the cellular DNA. The syringe was rinsed with $100 \mu$ l of water, and the rinse solution was added to the lysate. Thirty-two microliters of $5 \mathrm{M} \mathrm{NaCl}$ was added, mixed, followed by $720 \mu l$ of isopropanol, mixed by inversion, and stored at room temperature for $15 \mathrm{~min}$. DNA was recovered by centrifugation at $12,000 \mathrm{~g}$ for $10 \mathrm{~min}$, at $4^{\circ} \mathrm{C}$. The DNA pellet was redissolved in $360 \mu \mathrm{l}$ of TE, and $40 \mu \mathrm{l}$ of $3 \mathrm{M}$ sodium acetate ( $\mathrm{pH}$ 5.2) was added followed by an equal volume of isopropanol and stored at room temperature for $15 \mathrm{~min}$. The DNA was recovered by centrifugation at $4^{\circ} \mathrm{C}$ for $10 \mathrm{~min}$ at $12,000 \mathrm{~g}$. The supernatant was discarded, and the DNA was redissolved in $192 \mu$ l of TE followed by $8 \mu \mathrm{l}$ of $5 \mathrm{M} \mathrm{NaCl}$ and two 
volumes of ice-cold ethanol. The solution was stored on ice for $15 \mathrm{~min}$ to allow the DNA to precipitate. DNA was recovered by centrifugation at $4^{\circ} \mathrm{C}$ for 10 min. The DNA pellet was washed with $0.5 \mathrm{ml}$ of ice-cold $75 \%$ ethanol and centrifuged for $2 \mathrm{~min}$ at $4^{\circ} \mathrm{C}$. Ethanol was removed completely with a pipette tip, and the tube was left open at room temperature for $10 \mathrm{~min}$ to allow the residual ethanol to evaporate. The DNA pellet was resuspended in $100 \mu \mathrm{l}$ of $\mathrm{TE}$ at $65^{\circ} \mathrm{C}$ for at least $10 \mathrm{~min}$ and stored at $4^{\circ} \mathrm{C}$. Typically, $10 \%$ of the DNA solution was sufficient for PCR.

\section{Inactivation of Proteinase $\mathrm{K}$ with PMSF}

Phenylmethylsulfonyl fluoride (PMSF) is an irreversible inhibitor of proteinase $\mathrm{K} .{ }^{(11)}$ Thus, in certain exploratory experiments (see Results), the purified DNA samples in TE were made $1 \mathrm{~mm}$ in PMSF and incubated at $22^{\circ} \mathrm{C}$ for $15 \mathrm{~min}$. PMSF was then inactivated by adding Tris base ( $\mathrm{pH} \sim 10.5$ ) to a concentration of $20 \mathrm{~mm}$ and incubating the samples initially for $1 \mathrm{hr}$ at $22^{\circ} \mathrm{C}$, and then for $10 \mathrm{~min}$ at $65^{\circ} \mathrm{C}$. After cooling the samples to room temperature, DNA was precipitated by the addition of $250 \mathrm{~mm} \mathrm{NaCl}$ and two volumes of absolute ethanol, and for $1 \mathrm{hr}$ at $-20^{\circ} \mathrm{C}$. DNA was pelleted by a centrifugation at $12,000 \mathrm{~g}$ for $10 \mathrm{~min}$ at $4^{\circ} \mathrm{C}$, washed with $75 \%$ ethanol, air-dried for $10 \mathrm{~min}$, and redissolved in $\mathrm{TE}$ at $65^{\circ} \mathrm{C}$ for $10 \mathrm{~min}$.

\section{Assay for $\beta$-galactosidase}

$E$. coli $\beta$-galactosidase and the endogenous $\beta$-galactosidase were measured as described. ${ }^{(5)}$ One milliliter of assay mixture containing $80 \mathrm{~mm}$ sodium phosphate buffer (pH 7.3), 102 mм 2-mercaptoethanol, $9.0 \mathrm{~mm} \mathrm{MgCl}_{2}, 8 \mathrm{~mm}$ CPRG, and $200 \mu \mathrm{l}$ of cell lysate containing enzyme was incubated at $30^{\circ} \mathrm{C}$ for $1 \mathrm{hr}$. The increase in absorbance at $570 \mathrm{~nm}$ was measured at 15-min intervals. For the determination of $\beta$-galactosidase activity in untransfected and transfected cells, exactly the same number of cells was used in each case. Cell counting was done by using a Coulter counter (Coulter Electronics, Inc.). The preparation of cell extracts and lysis buffer used are as described. ${ }^{(5)}$

\section{Amplification of Transfected DNA}

Transfected plasmid DNA was amplified by a PCR procedure, based on that described by Saiki et al. ${ }^{(12)}$ A $10-\mu l$ DNA sample (typically $10 \%$ of the copurified mixture of electroporated plasmid DNA and the genomic DNA, isolated from cell nuclei) was added to a PCR mixture, which contained $10 \mathrm{~mm}$ Tris- $\mathrm{Cl}$ ( $\mathrm{pH} \mathrm{8.4)}$, $50 \mathrm{mM} \mathrm{KCl}, 2.25 \mathrm{mM} \mathrm{MgCl}_{2}, 200 \mu \mathrm{M}$ of each of the four deoxyribonucleotides (Pharmacia), $1 \mu \mathrm{M}$ (100 pmoles) of each primer (a molar excess of $\sim 10^{5}$ primer to template), $0.01 \%$ (wt/vol) of gelatin, and 2 units of Taq DNA polymerase (PerkinElmer Cetus) in a total reaction volume of $100 \mu \mathrm{l}$. When radioactive products were needed for quantitations, $1 \mu l$ (10 $\mu \mathrm{Ci})$ of $\left[\alpha^{-32} \mathrm{P}\right] \mathrm{dCTP}$ was included in the reaction mixture. Reactions were done in a thermal cycler (Perkin-Elmer Cetus TC-1) with 1 min of denaturation at $94^{\circ} \mathrm{C}, 2 \mathrm{~min}$ of annealing at $53^{\circ} \mathrm{C}$, and 2 min of polymerization at $70^{\circ} \mathrm{C}$. Finally, the mixture was subjected to postcycling treatment of primer extension at $70^{\circ} \mathrm{C}$ for $3 \mathrm{~min}$. At the end of the required number of cycles, $10 \mu$ l of each reaction mixture was mixed with $3.5 \mu$ l of $5 \times$ gelloading dye $(0.1 \%$ bromophenol blue, $0.5 \%$ SDS, 100 mM EDTA at pH 8.0, and $25 \%$ glycerol) and used for gel analysis.

\section{Analyses of PCR Products}

The PCR products were analyzed by electrophoresis in 7\% acrylamide gel (acrylamide/bis-acrylamide, $37.5: 1$ ), at $200 \mathrm{~V}$. The gel was stained with ethidium bromide $(0.5 \mu \mathrm{g} / \mathrm{ml})$ for $20 \mathrm{~min}$ for UV light visualization of DNA. For quantitations, the gel was soaked in an aqueous solution of $10 \%$ acetic acid and $10 \%$ methanol for $\sim 15 \mathrm{~min}$, dried, and autoradiographed. The resulting PCR-amplified bands were also quantitated using a PhosphorImager (Molecular Dynamics, Sunnyvale, CA).

\section{RESULTS}

\section{Strategy for Isolation of Transfected DNA involved in Gene Expression}

The procedures described were designed for the isolation of total plasmid DNA transfected into cell nuclei, whether integrated into cellular DNA or not. The isolate will also be free from residual plasmid not contributing to gene expres- sion, which might be trapped in the cell membranes or cytoplasm. Thus, isolation of clean and unruptured nuclei is an essential step in these procedures.

RNA and nuclear proteins were digested away from DNA by successive treatments with ribonuclease and proteinase K. Cellular DNA was partially sheared to facilitate subsequent manipulations. Cellular and transfected DNA were then copurified by a number of precipitations at room temperature to $0^{\circ} \mathrm{C}$ from alcoholic solutions containing appropriate concentrations of monovalent cations. Contaminants, such as proteinase $\mathrm{K}$, SDS, and EDTA, were virtually eliminated from these preparations, and the purified DNA was sufficiently clean for amplification by PCR.

\section{Recovery and Detection of Transfected DNA}

Initially, attempts were made to quantitate transfected DNA by DNA-DNA hybridization. Thus, 5 - to $20-\mu$ g quantities of BAG plasmid were electroporated into different cell lines. DNA from untransfected and transfected cells were prepared as described, digested with BamHI restriction enzyme, and bound to $\mathrm{Hy}$ bond N-Nylon membrane, using a slot blot apparatus. The membrane-bound DNA samples were subsequently hybridized to a nick-translated ${ }^{32} \mathrm{P}$-labeled 533bp HindIII-PstI neomycin gene fragment of the pMEXneo plasmid. ${ }^{(13)}$ Even under the most stringent conditions, it was not possible to detect significant differences between the signals generated by DNA samples from transfected and untransfected cells (data not shown). The results suggested that the amount of transfected DNA isolated from the cells was below the limit of detection by hybridization and that an alternative approach was required for detection.

PCR is a much more sensitive technique than hybridization. Because PCR specifically amplifies the target DNA, the signal-to-background ratio is usually very high. To quantitate transfected plasmid DNA by PCR, a pair of primers, Lac-1 (5'-GCCAGCTGGCGTAATAGCGA) and Lac-2 (5'-ACGGCGGATTGACCGTAATG) were designed. These primers are complementary to the DNA sequences corresponding to the $\alpha$-peptide of the lacZ ( $\beta$ galactosidase) gene, ${ }^{(14)}$ which is present in bacteriophage M13mp, plasmid pUC, and the derivative vectors including 
pBAG. This pair of primers specifically amplified a 238-bp DNA fragment when pBAG was used as template in PCR (Fig. 1). To demonstrate that extraction of plasmid DNA by the procedure described is quantitative, $20 \mathrm{ng}$ of pBAG DNA was mixed with nuclei isolated from $10^{7}$ Rat-1 cells, and divided into equal halves. The genomic plus the plasmid DNA from each half were purified independently as described above. One-tenth of each DNA sample, theoretically containing $1 \mathrm{ng}$ of plasmid DNA, was amplified by 15 cycles of PCR, in parallel with $1 \mathrm{ng}$ of standard pBAG DNA. Each amplified DNA sample (10\%) was analyzed on a $7 \%$ acrylamide gel and stained with ethidium bromide. Figure $1 \mathrm{~A}$ shows that the intensity of the 238-bp bands corresponding to the two plasmid samples copurified with the genomic DNA (lanes $1,2)$ are equivalent to the standard pBAG band (lane 3 ). This PCR experiment was repeated using $\left[\alpha-{ }^{32} \mathrm{P}\right] \mathrm{dCTP}$, the products quantitated by PhosphorImager (Fig. $1 \mathrm{~B}, \mathrm{C})$. The amplification product for 1 ng of standard plasmid BAG DNA (lane 1) and $1 \mathrm{ng}$ of pBAG coextracted with genomic DNA (lane 2) were equal, suggesting that the recovery of plasmid DNA by this method is close to $100 \%$. Genomic DNA alone does not produce a PCR band of 238 bp (lane 3). DNA extracted from the nuclei of Rat- 1 cells, 24 $\mathrm{hr}$ after electroporation with $\mathrm{pBAG}$, generated the same 238-bp PCR product (lane 4). The residues from each of the DNA purification steps were analyzed ex- tensively by PCR, and by analysis of the UV light spectrum (data not shown). There was no loss of DNA during any of the purification steps when $20-50 \mu \mathrm{g}$ of genomic DNA was present during purification. However, when lower quantities of carrier or genomic DNA were present, the yield was not always quantitative.

\section{Quantitative PCR}

Under our experimental conditions, with a primer-to-template molar ratio of $10^{5}: 1$, and for low number of PCR cycles (9-15), the relationship between the initial template quantity in the PCR reaction (from $10^{6}-10^{10}$ template copies tested) and the accumulation of the specifically amplified PCR products follows a linear curve (Fig. 2). All of the plasmid DNA standard samples were diluted with the same genomic DNA solution, so that the concentration of genomic DNA in the standard plasmid samples was approximately the same as in the experimental samples. In this way, any bias with respect to genomic DNA differences between experimental and standard samples were eliminated, although this extra precaution is not strictly necessary. DNA concentrations or plasmid copy numbers in the experimental samples could be directly read from a linear plot of PhosphorImager values versus standard plasmid concentrations (or template copy numbers).

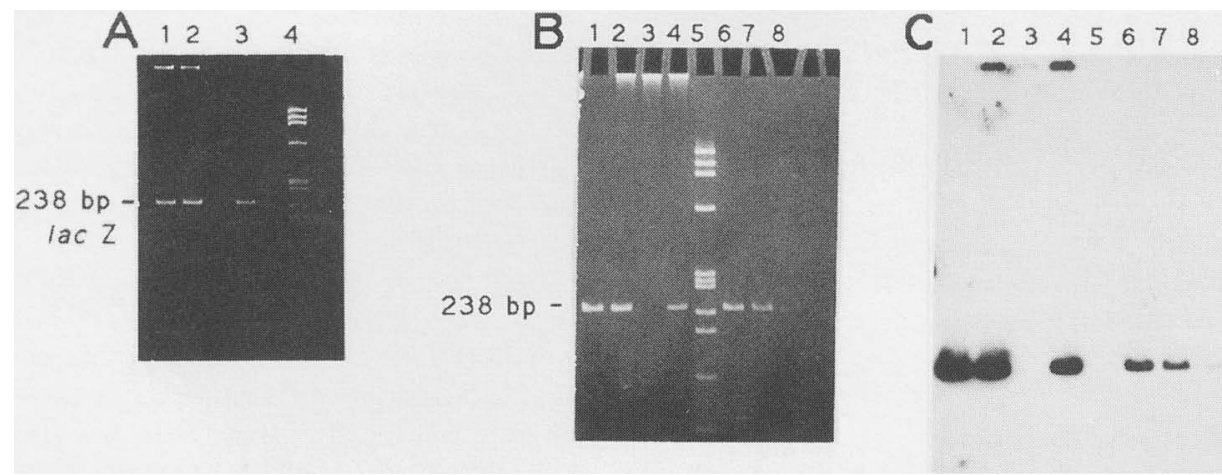

FIGURE 1 Analyses of the 238-bp lacZ DNA after 15 cycles of amplification. An aliquot of each PCR reaction was electrophoresed through a $7 \%$ acrylamide gel and stained with ethidium bromide. (A) (Lane 1) 1 ng of pBAG DNA copurified with Rat-1 nuclear DNA; (lane 2 a duplicate DNA preparation as in lane 1; (lane 3) $1 \mathrm{ng}$ of standard pBAG DNA; (lane 4) $1.5 \mu \mathrm{g}$ of $\phi X 174 \mathrm{RF}$ DNA/HaellI fragments. $(B, C)$ (Lane 1$) 1 \mathrm{ng}$ of plasmid BAG DNA; (lane 2$) 1 \mathrm{ng}$ of pBAG copurified with genomic DNA; (lane 3) genomic DNA; (lane 4) DNA isolated from Rat-1 cell nuclei at $24 \mathrm{hr}$ posttransfection with $5 \mu \mathrm{g}$ of pBAG; (lane 5) $1.5 \mu \mathrm{g}$ of nonradioactive $\phi X 174 /$ HaelII DNA fragments; (lanes $6-8) 100,10$, and 1 pg of pBAG DNA, respectively. $(A, B)$ Ethidium bromide stained; (C) autoradiograph of PCR products shown in $B$ labeled with $\left[\alpha-{ }^{32} \mathrm{P}\right] \mathrm{dCTP}$.

\section{Expression of $\beta$-galactosidase Gene from Mo-MuLV LTR Promoter in Different Cell Lines}

We next studied the transient expression of E.coli $\beta$-galactosidase gene from a constitutive promoter, the wild-type MoMuLV LTR, in different cell lines. Rat-1 fibroblast cells, FBJ v-fos-transformed Rat-1 cells (1302), and the revertant EMS-1-19 cells $^{(8)}$ were transfected with $10 \mu \mathrm{g}$ of pBAG. Cells were harvested at 22 and $48 \mathrm{hr}$ posttransfection. Each lot of transfected cells was divided into equal halves. One half was used for preparation of cell extract and enzyme assay, and the other half was used to prepare nuclei and nuclear DNA for PCR. Figure 2A shows the autoradiograph of the standard DNA samples as well as the experimental samples from such an analysis. The plot of the PhosphorImager values of the standard DNA samples, from which the amounts of transfected plasmid DNA were directly read, is shown in Figure 2B.

The time course of $\beta$-galactosidase reactions are shown in Figure 3. The level of endogenous (cellular) $\beta$-galactosidase activity is dependent on cell type and number. Therefore, the exact cell number from the same cell type was used for determination of endogenous activity, which was then subtracted from the total (transgene plus endogenous) activity. The results demonstrated that the specific expression (transgene $\beta$-galactosidase activity/plasmid) for the $\mathrm{v}$-fos-transformed cell line (1302) is significantly higher than for the other cell lines (Table 1). For $22 \mathrm{hr}$ posttransfection, the ratio of specific expression of $\beta$-galactosidase activity of 1302 to Rat-1 or EMS-119 was approximately $4: 1$; for $48 \mathrm{hr}$ posttransfection, the ratio of 1302 to Rat- 1 was $>10: 1$, and the ratio of 1302 to EMS-1-19 was 2.6:1.

\section{Effect of PMSF Treatment of DNA on PCR Products}

Proteinase $\mathrm{K}$, used in DNA purification procedures, is a powerful and stable serine protease, which is not easily inactivated by heating. If significant proteinase $\mathrm{K}$ activity remains in DNA samples, it could digest Taq DNA polymerase and reduce the yield of PCR products to different extents in different reactions. The conventional ways for inactivation of proteinase $\mathrm{K}$ involve extensive phenol 

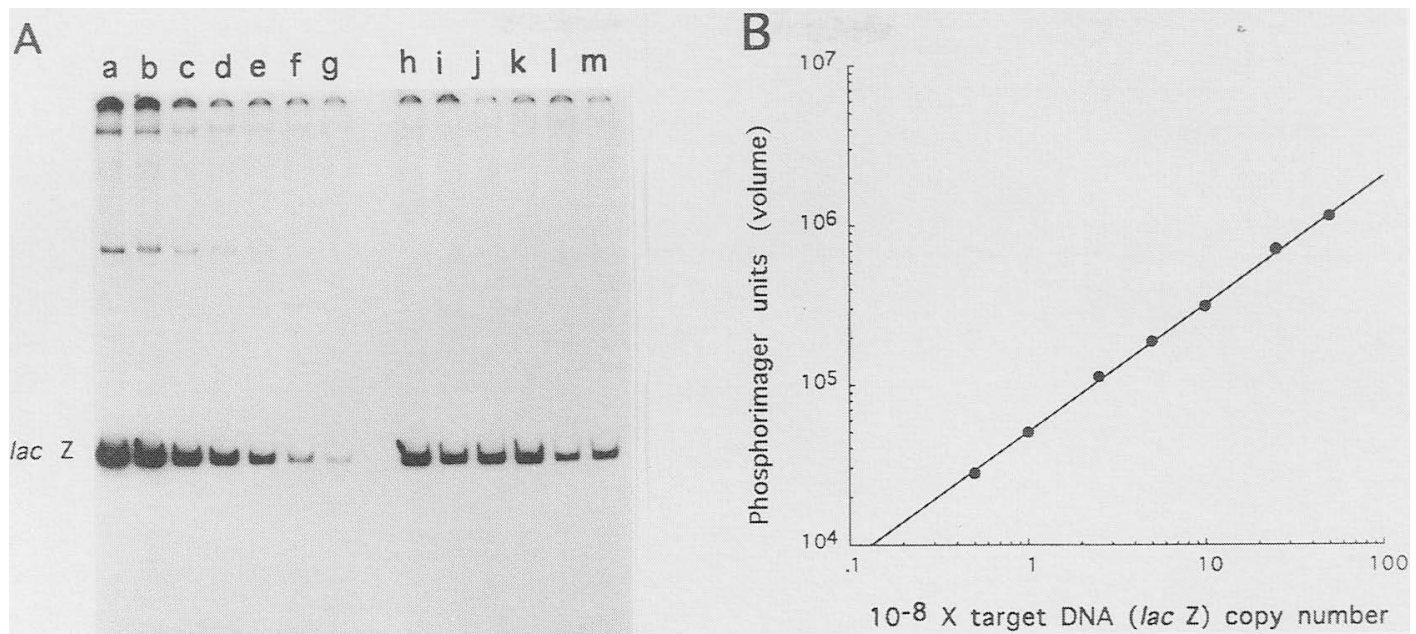

FIGURE 2 PCR amplification products of bacterial lacZ DNA isolated from transfected cell nuclei. Various cell lines were electroporated with $10 \mu \mathrm{g}$ of pBAG. At 22 and $48 \mathrm{hr}$ after electroporations, the cells from each transfection were harvested and divided in equal halves; one half was used for nuclei, and the other for cell extract preparations. One-tenth of DNA isolated from each nuclei sample, along with a set of standard pBAG samples, was amplified by 10 PCR cycles, as described in Materials and Methods. $(A)$ Autoradiograph of $\left[\alpha-{ }^{32} \mathrm{P}\right] \mathrm{dCTP}-\mathrm{labeled}$ PCR products. (Lanes $a-g$ ) The PCR products for standard PBAG DNA samples with $50,25,10,5,2.5,1$, and $0.5 \times 10^{8}$ copies, respectively; PCR products of electroporated pBAG DNA samples in various cell lines, after the indicated posttransfection times: (Lane $h$ ) Rat-1 (22 hr); (lane $i) 1302$ (22 hr); (lane $j$ ) EMS-1-19 (22 hr); (lane k) Rat-1 (48 hr); (lane l) 1302 (48 hr); (lanie $m$ ) EMS-1-19 (48 hr). One-tenth of each PCR-amplified sample was analyzed on a 7\% acrylamide gel. (B) A plot of Phosphorlmager volumes obtained from individual PCR amplified lacZ-specific bands (shown in $A$, pBAG standards) vs. the number of target DNA molecules used in each reaction.

extractions, or treatment with PMSF, which inhibits the enzyme irreversibly. The following experiment was performed to confirm that the proteinase $\mathrm{K}$ was absent in the DNA preparations for PCR. DNA from each of the three cell lines, Rat-1, 1302, and EMS-1-19, was prepared from cells transfected with
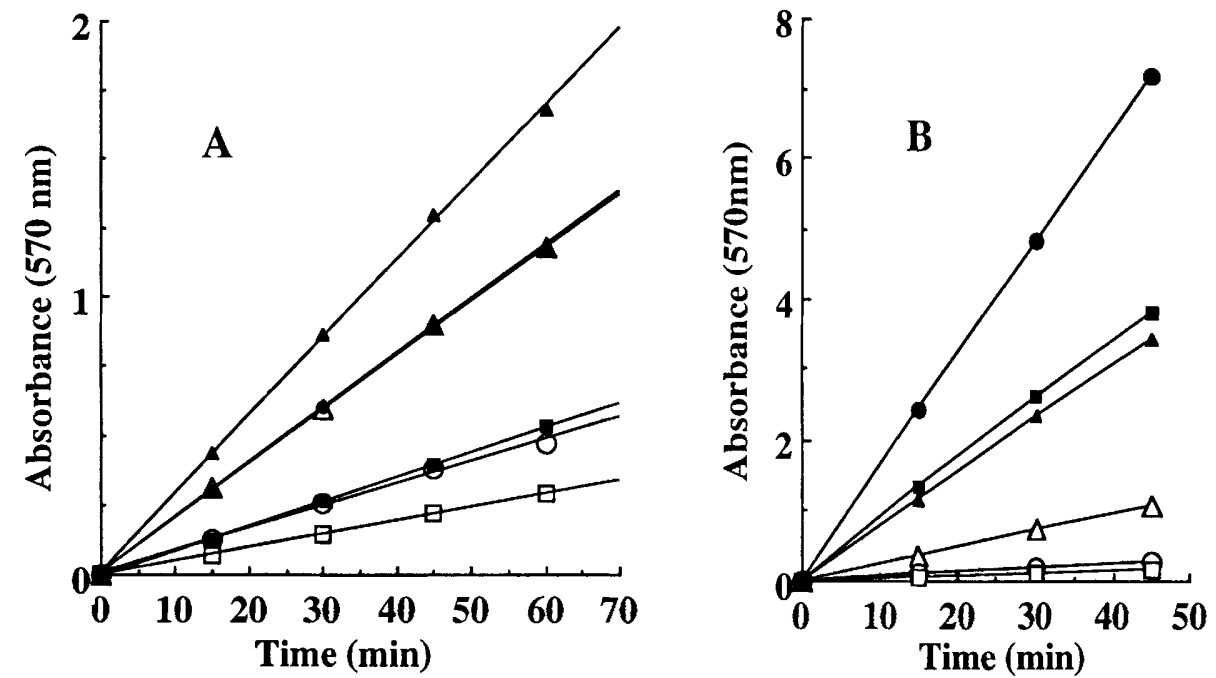

FICURE 3 Time course of $\beta$-galactosidase activity for various cell types and transfectants at $22(A)$ or $48 \mathrm{hr}(B)$ post-transfection. Equal numbers of cells were used for each pair of untransfected and pBAG-transfected cell extract preparations. An increase in $A_{570}$ for the total extract as a function of time is shown in each case. $(\triangle)$ Untransfected Rat-1; $(\mathbf{\Delta})$ pBAG-transfected RAT-1; $(O)$ un-

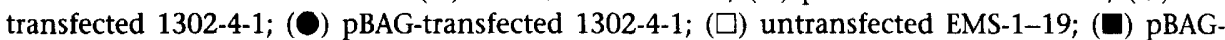
transfected EMS-1-19.
pBAG after 22 and $48 \mathrm{hr}$. Each DNA sample was dissolved in $100 \mu \mathrm{l}$ of TE, $10 \mu \mathrm{l}$ of which was saved for PCR. The rest of the sample was treated with PMSF. Each DNA sample was then resuspended in 90 $\mu l$ of $\mathrm{TE}, 10 \mu \mathrm{l}$ of which was saved for comparison with untreated fraction. Figure 4 shows the autoradiograph of the
PCR products for $1 \mathrm{ng}$ (lane 1 ) and $10 \mathrm{ng}$ (lane 2) of pBAG standard DNA, as well as six pairs of untreated and PMSFtreated electroporated DNA samples (lanes 3-14). It is clear from these data that within experimental error (maximum 15\%) between the two fractions of each pair of PCR products, there was no significant and consistent increase in the PCR products of the PMSF-treated DNA samples.

\section{Plasmid DNA-Nuclei Interactions}

The protocol described above was designed to measure the number of plasmids present in the nuclei of transfected cells at the time that the transcription rate is determined in the same cells. Nevertheless, it is possible that transfected plasmid DNA molecules could escape the nuclei during centrifugation. The following experiment was conducted to test this hypothesis. The nuclei from Rat- 1 cells electroporated with $10 \mu \mathrm{g}$ of pBAG were purified, resuspended in 200 $\mu l$ of isotonic nuclear buffer and centrifuged for $10 \mathrm{~min}$ at $1100 \mathrm{~g}$ at $4^{\circ} \mathrm{C}$. The nuclear pellet was saved. The supernatant was mixed with $5 \mu \mathrm{g}$ of carrier Rat- 1 cell genomic DNA, the DNA was precipitated with ethanol, and resuspended in $10 \mu \mathrm{l}$ of TE. The whole of this DNA sam- 
TABLE 1 Comparison of Transient Expression of the $E$. coli $\beta$-galactosidase Gene from Mo-MuLV LTR in Different Cell Lines at 22 and $48 \mathrm{hr}$ Post-transfection

\begin{tabular}{|c|c|c|c|c|c|c|}
\hline \multirow{2}{*}{$\begin{array}{l}\text { Transfection } \\
\text { (cell/plasmid) }\end{array}$} & \multicolumn{3}{|c|}{$\begin{array}{c}\beta \text {-galactosidase } \\
\text { activity }\left(A_{570} / \mathrm{hr}\right)\end{array}$} & \multirow{2}{*}{$\begin{array}{l}\text { Plasmid } \\
\text { number } \\
\left(10^{-9} \times\right)\end{array}$} & \multirow{2}{*}{$\begin{array}{l}\text { Specific transgene } \\
\text { expression }\left(10^{9} \times\right) \text { : } \\
\beta \text {-galactosidase } \\
\text { activity } / \text { pBAG }\end{array}$} & \multirow{2}{*}{$\begin{array}{l}\text { Specific } \\
\text { expression } \\
\text { ratios }\end{array}$} \\
\hline & cellular & cellular $+\mathrm{pBAG}$ & $\mathrm{pBAG}$ & & & \\
\hline \multicolumn{7}{|c|}{$22 \mathrm{hr}$ after transfection } \\
\hline Rat-1/BAG & 1.18 & 1.70 & 0.52 & 10.0 & 0.05 & 1.0 \\
\hline 1302/BAG & 0.49 & 1.18 & 0.69 & 3.3 & 0.21 & 4.0 \\
\hline 1-19/BAG & 0.29 & 0.53 & 0.24 & 4.2 & 0.06 & 1.1 \\
\hline \multicolumn{7}{|c|}{$48 \mathrm{hr}$ after transfection } \\
\hline Rat-1/BAG & 1.40 & 4.55 & 3.15 & 5.1 & 0.62 & 1.0 \\
\hline 1302/BAG & 0.33 & 9.53 & 9.20 & 1.4 & 6.57 & 10.6 \\
\hline 1-19/BAG & 0.22 & 5.22 & 5.00 & 2.0 & 2.50 & 4.0 \\
\hline
\end{tabular}

Each cell line was electroporated with $10 \mu \mathrm{g}$ of plasmid BAG. The number of untransfected cells used for cellular $\beta$-galactosidase determination were made exactly equal to the transfected cells. Thus, the value for bacterial $\beta$-galactosidase activity was calculated by subtraction of the endogenous $\beta$-galactosidase activity from the total activity.

${ }^{a}$ The specific bacterial gene expression values obtained from duplicate experiments varied by a maximum of $20 \%$.

ple was placed in one PCR tube and amplified with Lac-1 and Lac-2 primers for 15 cycles. No detectable amount of lacspecific product could be seen after this amplification (Fig. 5, lane g). The results obtained with standard pBAG DNA samples, 25-0.05 ng, PCR amplified for 15 cycles are shown in Figure 5 (lanes $\mathrm{a}-\mathrm{f}$ ). An aliquot containing $2 \%$ of the DNA extracted from the nuclei of Rat-1, 1302, and EMS-1-19 cells, transfected with pBAG, were also amplified under the same conditions (Fig. 5, lanes i-k). These results indicated that $<5 \times 10^{6}$ copies of the transfected plasmid DNA $(<0.5 \%)$ could have escaped the nuclei.

We also investigated the affinity of nuclei for plasmid DNA, and/or the rate of uptake of pBAG by the cell nuclei. Thus, nuclei from one confluent plate $\left(\sim 10^{7}\right.$ cells) of 1302 cells were isolated, mixed with $2 \mu \mathrm{g}$ of pBAG in $100 \mu \mathrm{l}$ of ice-cold lysis buffer, and incubated on ice for $10 \mathrm{~min}$. The nuclei were then

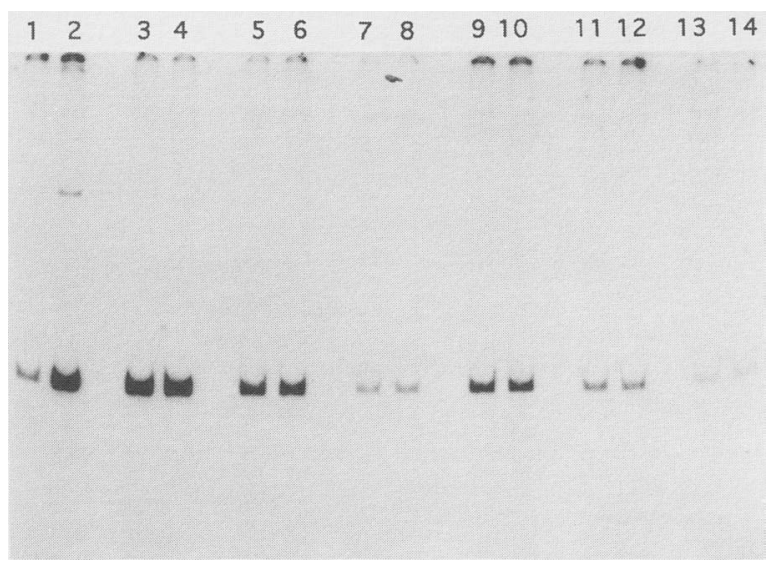

FIGURE 4 Analyses of the PCR products for six pairs of pBAG-transfected nuclear DNA samples, untreated vs. PMSF-treated. Autoradiograph of $\left[\alpha^{32} \mathrm{P}\right] \mathrm{dCTP}$-labeled PCR amplification products generated after 10 cycles with Lac-1 and Lac-2 primers. One nanogram of pBAG standard DNA (lane 1); 10 ng of pBAG standard DNA (lane 2); Rat-1/pBAG, 22 hr post-transfection (lanes 3,4); 1302/pBAG, 22 hr post-transfection (lanes 5,6;1-19/pBAG, $22 \mathrm{hr}$ post-transfection (lanes 7,8); Rat-1/pBAG, $48 \mathrm{hr}$ post-transfection (lanes 9,10); 1302/pBAG, $48 \mathrm{hr}$ post-transfection (lanes 11,12); 1-19/pBAG, $48 \mathrm{hr}$ post-transfection (lanes 13,14). (Lanes 4,6,8,10,12,14) DNA samples treated with PMSF prior to PCR amplifications. Phosphorlmager volumes for the lac-specific PCR-amplified bands, for each, are, respectively, 29,000;289,000;212,600;186,200; 81,700; 87,$900 ; 19,200 ; 20,700 ; 63,300 ; 70,000 ; 25,800 ; 26,000 ; 7,900 ; 9,200$ (lane $1-14$ ).

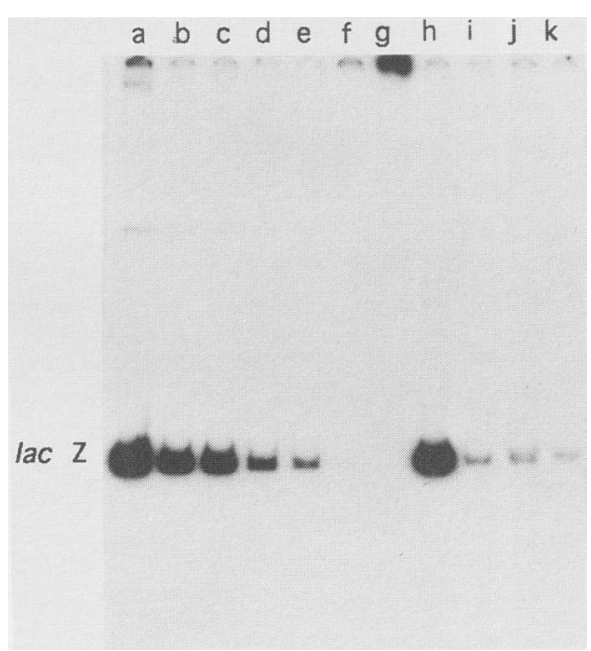

FIGURE 5 Interactions of plasmid DNA with nuclei. Autoradiograph of $\left[\alpha^{32} \mathrm{P}\right] \mathrm{dCTP}$-labeled PCR amplification products generated after 15 cycles with Lac- 1 and Lac-2 primers. (Lanes $a-f$ ) Standard pBAG DNA, 25, 5, 5, 1, 0.5 , and $0.05 \mathrm{ng}$, respectively; (lane $\mathrm{g}$ ) supernatant fraction from centrifugation of purified, electroporated Rat-1 nuclei with $10 \mu \mathrm{g}$ of pBAG, as described in Results, (lane $h$ ) $10 \%$ of the nuclear DNA of 1302 cells after incubation of these nuclei with $2 \mu \mathrm{g}$ of pBAG for $10 \mathrm{~min}$ and three washings with $2 \mathrm{ml}$ of buffer. Rat-1, 1302, and EMS-1-19 cells, respectively, each electroporated with $10 \mu \mathrm{g}$ of pBAG, $2 \%$ of each nuclear DNA sample isolated $48 \mathrm{hr}$ posttransfection were amplified (lanes $i-k$ ).

washed three times with $2 \mathrm{ml}$ of cold lysis buffer. An aliquot containing $10 \%$ of the DNA purified from these nuclei was amplified by PCR for 15 cycles (Fig. 5, lane $\mathrm{h}$ ). Theoretically, $<0.002 \mathrm{ng}$ of plasmid DNA should have remained with the nuclei if no strong interaction was present. However, the results indicated that $10 \%$ of the mixed plasmid DNA remained associated with the nuclei after washings. This result suggested a very strong affinity of nuclei for DNA. Most of the associated plasmid DNA could have entered the nuclei in such a short time.

\section{DISCUSSION}

A major problem in studying the effects of promoters and enhancers on gene expression is the accurate determination of the transgene introduced into the cell nuclei, that is, the transfection efficiency. Even though satisfactory results have been obtained using the cotransfection method within one cell type, this 
method has not proved to be generally convenient and applicable to every system. This is particularly true when comparative gene expression studies are done between different cell lines. Therefore, a direct and universal method for quantification of transfected DNA has become a necessity in the studies of gene expression. In this laboratory, the biochemical pathways of oncogene-induced cell transformation are being investigated. To this end, a series of revertants from v-fos-transformed Rat-1 fibroblasts have been isolated, which has sustained inactivating mutations in cellular transformation effector genes. ${ }^{(8)}$ During the study of differential gene expression among these cell lines, it was observed that the activity of constitutive promoters can vary as much as 10 -fold when transfected into these different cells (C.D. Hoemann and H. Zarbl, unpubl.).

In this report a PCR-based method for direct quantitation of transfected plasmid DNA in nuclei is described. In addition, a relatively simple procedure is described for quantitative purification of transfected DNA from cell nuclei, without the use of phenol or other organic solvent extractions. This procedure quantitatively yields DNA of high purity (ribonuclease and protease treated, and $A_{260} / A_{280}$ of about 1.97 in $50 \mathrm{~mm} \mathrm{NaCl}$ ), suitable for quantitation by PCR. Although other rapid and simpler methods for DNA extraction ${ }^{(15,16)}$ have been described, it is not clear that they could be directly used to produce equally good results.

Shortly after the advent of PCR, the possibility of using this new molecular technique for quantitative purposes was explored by several groups. PCR is a highly sensitive and efficient method for in vitro amplification of a specific gene of interest, using genomic DNA as template. Furthermore, after synthesis of a cDNA using reverse transcriptase, specific RNA molecules may also be amplified in vitro. Therefore, the potential of this method for quantitative analysis of a gene or gene expression from small numbers of cells is enormous. ${ }^{(17)}$

However, it was noted that repetitive experiments using both identical PCR conditions and identical amounts of the same template DNA did not necessarily lead to identical amounts of amplification products. For example, when a master mix containing all of the reagents, including template DNA, was prepared and divided equally into several tubes, the yield of the amplified product varied as much as sixfold. ${ }^{(18)}$ An explanation may be that the efficiency of PCR is affected by even minute differences in concentration of reagents present in the sample, as well as by small differences in temperature depending on the position of the reaction tube in the heat block of the thermal cycler. ${ }^{(19)}$ Thus, PCR did not seem to be a reliable quantitative assay. (17)

Methods have been described recently that allow PCR to be used for quantitation of the copy number of a gene in genomic DNA and the cDNA made from mRNA. These include differential PCR, ${ }^{(17,20,21)}$ which in the same reaction tube for target gene or cDNA coamplified a single copy endogenous reference gene or cDNA by using an additional pair of primers. The copy number of the target sequence in the initial sample was estimated by comparing the intensity of the amplification products of the target sequence and the reference sequence. An alternative approach is termed competitive PCR, ${ }^{(17,18,22,23)}$ and an improved variation is termed tandem competitive PCR. ${ }^{(24)}$ These approaches include a competitive synthetic template (an internal standard) in the amplification reaction that uses the same set of primers and is coamplified with the target template. The advantages and the limitations of these methods have been reviewed in some detail. ${ }^{(17)}$ All of these methods share the features of complexity-indirect and often multistep quantitation, labor intensive and costly, and applicable only to a particular system. Although certain genes and mRNAs have been quantitated successfully by these methods, some obvious limitations exist. A special vector needs to be constructed to serve as internal standard for every system. The internal standard seems to have an amplification advantage over the target gene and frequently is amplified more effciently. While the competitive DNA was usually amplified with an efficiency correlating to the amount of vector DNA in the initial sample, amplification of genomic DNA in the same reaction tubes and using the same set of primers frequently did not yield products of gradual increasing intensity. ${ }^{(17)}$ A disadvantage of using a single-copy reference gene for quantitative PCR is the need for a second pair of primers for coamplification of the en- dogenous internal standard gene. Under conditions used for amplification of the target gene, another pair of primers may amplify with different efficiency. While low levels of increase in copy number of the target gene could be identified, the level of amplification could only be estimated and not be determined precisely. ${ }^{(17)}$ Also, a linear correlation between the neu gene to the reference gene $\gamma$-interferon ratio and the level of amplification of the neu gene in breast carcinoma cell lines could not be established. ${ }^{(20)}$

The quantitative PCR method described here was designed for accurate measurement of transfected DNA for transient gene expression studies. It has the advantage of simplicity combined with accuracy and reproducibility. Even when different primers such as exon-5 human growth hormone (hGH) or chloramphenicol acetyl transferase (CAT) were used, there was no difficulty in quantitating the amount of transfected DNA (data not shown). It is important to note that amplified template molecules can reanneal to themselves and compete strongly with primer molecules. All the amplifications were thus performed with a low number of PCR cycles $(<15$, usually 9-10). The primer-to-template ratio used was such that at the last PCR cycle it would be in excess of 10-fold.

The differential transient expression of $E$. coli $\beta$-galactosidase gene from a constitutive promoter (wild-type MoMuLV LTR) in Rat-1 fibroblast cells, FBJ v-fos-transformed Rat-1 cells (1302), and the revertant EMS-1-19 cells was studied. The results of this experiment (Table 1) showed that the products of the transgene expression accumulate at a much greater rate in the transformed 1302 cell line than in normal Rat-1 cells, 4-fold higher at $22 \mathrm{hr}$, and $>10$-fold at $48 \mathrm{hr}$ posttransfection. Compared with EMS1-19 cells, transgene product accumulation in 1302 cells was also 4-fold higher at $22 \mathrm{hr}$ posttransfection, but at $48 \mathrm{hr}$ this ratio was only $\sim 2.6$. Many factors could contribute to the observed differences in the specific transgenic $\beta$-galactosidase activity in various cell types. These include promoter activity, mRNA and protein stability, and cell doubling time. The revertant EMS-1-19 cells, for example, divide at least three times slower than Rat-1 cells. Gene expression results are usually analyzed $48 \mathrm{hr}$ after transfection to obtain measurable levels 
of cotransfected $\beta$-galactosidase activity. Hence, a lack of knowledge about the expression level of such internal control genes in various cell types could lead to the generation of erroneous normalized data and conclusions. We believe that the values shown for the expression of $\beta$-galactosidase transgene in different cell lines may only hold true for this particular gene and promoter system. Other endogenous or transgenes could exhibit different results in the same three cell types. Therefore, the cotransfection method may be unsuitable for normalization of ectopic gene expression data in different cell lines. Direct determination of the transgene copy number within the nuclei of transfectants, using the methods described in this manuscript, is a viable alternative. Even for gene expression studies within the same cell type, direct quantitation of transfected DNA is a much more reliable method than an indirect, cotransfection procedure. It is also less labor intensive and reduces the number of independent determinations needed in each experiment to establish valid results.

The results in Figure 4 demonstrate two important issues. First, the DNA samples prepared by our methods appear to be free from proteinase $K$ activity, which could potentially degrade Taq DNA polymerase in the PCR reaction and interfere with the quantitation of transfected DNA. Second, they demonstrate the reproducibility of the PCR reactions even after samples were treated with PMSF and repurified.

The experiments in Figure 5 indicated that no detectable amount of transfected plasmid DNA is lost from the nuclei during nuclei purification. On the contrary, the plasmid DNA appeared to be taken up very efficiently by the nuclei. After a 10 -min incubation, $10 \%$ of the DNA remained strongly associated with the nuclei. It is generally accepted that the transfected DNA does not remain intact in the cytoplasm several hours after transfection, as it would be degraded by cellular nucleases. Therefore, the transfected DNA needs to be rescued efficiently by the nuclei. If a certain fraction of nuclear-associated, transfected DNA remained intact and associated with the nuclear outer membrane several hours posttransfection, one would assume that proportionally this fraction would be comparable in different cell types. It would be difficult to determine the pre- cise location of every transfected DNA molecule that is strongly associated with cell nucleus.

In conclusion, because the traditional cotransfection procedures could yield erroneous normalized results, true comparisons of gene expression between different cell lines depend on direct quantitation of the transfected DNA by a reliable method. The procedures described in this report make the achievement of this objective possible. Moreover, even for comparisons of gene expression levels within a cell line, the methods described here greatly simplify the task of normalization of data for transfection efficiency. Every single determination by this method is less time consuming and more accurate than a gene product determination from a cotransfected vector. Using our approach, a single repetition of each experiment is sufficient to indicate the reproducibility of results, whereas 5-12 determinations are often necessary to lower the standard error of the mean to an acceptable level in experiments using cotransfection. Thus, while our method will help improve the study of gene regulation in normal versus tumor cells, and on studies of differential gene expression during cell differentiation, it will also simplify studies that require quantitative analysis of ectopic promoter activities.

\section{ACKNOWLEDGMENTS}

We thank Drs. Michael Breindl, Uttam L. RajBhandary, and Paul Bornstein for helpful discussions. This work was supported by grant 1-RO-1-CA50378 from the National Cancer Institute, National Institutes of Health M.B.B. was the recipient of a toxicology training grant (2T32-ES07020) from the National Institute of Environmental Health Sciences.

\section{REFERENCES}

1. Sambrook, J., E.F. Fritsch, and T. Maniatis. 1989. Strategies for studying gene regulation, p. 16.56. In: Molecular cloning: $A$ laboratory manual, 2nd ed. Cold Spring Harbor Laboratory Press, Cold Spring Harbor, New York.

2. Hall, C.V., P.E. Jacob, G.M. Ringold, and F. Lee. 1983. Expression and regulation of Escherichia coli lac $\mathrm{Z}$ gene fusions in mammalian cells. J. Mol. Appl. Genet. 2: 101109.

3. Herbomel, P., B. Bourachot, and M. Ya- niv. 1984. Two distinct enhancers with different cell specificities coexist in the regulatory region of polyoma. Cell 39: 653-662.

4. Edlund, T., M.D. Walker, P.J. Barr, and W.J. Rutter. 1985. Cell-specific expression of the rat insulin gene: Evidence for role of two distinct $5^{\prime}$ flanking elements. Science 230: 912-916.

5. Eustice, D.C., P.A. Feldman, A.M. ColbergPoley, R.M. Buckery, and R.H. Neubauer. 1991. A sensitive method for the detection of $\beta$-galactosidase in transfected mammalian cells. BioTechniques 11: 739742.

6. Majumdar, D., Y.J. Avissar, and J.H. Wyche. 1991. Simultaneous and rapid isolation of bacterial and eukaryotic DNA and RNA: A new approach for isolating DNA. BioTechniques 11: 94-101.

7. Chevillard, S. 1993. A method for sequential extraction of RNA and DNA from the same sample, specially designed for a limited supply of biological material. BioTechniques 15: 22-24.

8. Zarbl, H., J. Latreille, and P. Jolicoeur. 1987. Revertants of v-fos transformed fibroblasts have mutations in cellular genes essential for transformation by other oncogenes. Cell 51: 357-369.

9. Price, J., D. Turner, and C. Cepko. 1987. Lineage analysis in the vertebrate nervous system by reterovirus-mediated gene transfer. Proc. Natl. Acad. Sci. 84: 156160.

10. Cochran, B.H., J. Townes, and T.E. Hayes. 1988. Transcriptional regulation of competence genes in BALB/C-3T3 cells. In Cellular factors in development and differentiation: Embryos, teratocarcinomas, and differentiated tissues (ed. S.E. Harris, and P.E. Mansson), pp. 225-241, Alan R. Liss, New York.

11. Ebeling, W., N. Hennrich, M. Klockow, H. Metz, H.D. Orth, and H. Lang. 1974. Proteinase $\mathrm{K}$ from Tritirachium album Limber. Eur. J. Biochem. 47: 91-97.

12. Saiki, R.K., D.H. Gelfand, S. Stoffel, S.J. Scharf, R. Higuchi, G.T. Horn, K.B. Mullis, and H.A. Erlich. 1988. Primer-directed enzymatic amplification of DNA with a thermostable DNA polymerase. Science 239: 487-491.

13. Martin-Zanca, D., R. Oskam, G. Mitra, T. Copeland, and M. Barbacid. 1989. Molecular and biochemical characterization of the human trk proto-oncogene. Mol. Cell. Biol. 9: 24-33.

14. Yanisch-Perron, C., J. Vieira, and J. Messing. 1985. Improved M13 phage cloning vectors and host strains: Nucleotide sequences of the M13mp18 and pUC19 vectors. Gene 33: 103-119.

15. Winberg, G. 1991. A rapid method for preparing DNA from blood, suited for PCR screening of transgenes in mice. $P C R$ Methods Applic. 1: 72-74. 
16. Lewin, H.A. and J.A. Stewart-Haynes. 1992. A simple method for DNA extraction from leukocytes for use in PCR. BioTechniques 13: 522-523.

17. Volkenandt, M., A.P. Dicker, D. Banerjee, R. Fanin, B. Schweitzer, T. Horikoshi, K. Danenberg, P. Danenberg, and J.R. Bertino. 1992. Quantitation of gene copy number and mRNA using the polymerase chain reaction. Proc. Soc. Exp. Biol. Med. 200: 1-6.

18. Gilliland, G., S. Perrin, K. Blanchard, and H.F. Bunn. 1990. Analysis of cytokine mRNA and DNA: Detection and quantitation by competitive polymerase chain reaction. Proc. Natl. Acad. Sci. 87: 27252729.

19. Linz, U. 1990. Thermocycler temperature variation invalidates PCR results. BioTechniques 9: 286-293.

20. Frye, R.A., C.C. Benz, and E. Liu. 1989. Detection of amplified oncogenes by differential polymerase chain reaction. Oncogene 4: 1153-1157.

21. Noonan, K.E., C. Beck, T.A. Holzmayer, J.E. Chin, J.S. Wunder, I.L. Andrulis, A.F. Gazdar, C.L. Willman, B. Griffith, D.D. Von Hoff, and I.B. Roninson. 1990. Quantitative analysis of MDRI (multidrug resistance) gene expression in human tumors by polymerase chain reaction. Proc. Natl. Acad. Sci. 87: 7160-7164.

22. Wang, A.M., M.V. Doyle, and D.F. Mark. 1989. Quantitation of mRNA by the polymerase chain reaction (published erratum appears in Proc. Natl. Acad. Sci. 1990. 87: 2865). Proc. Natl. Acad. Sci. 86: $9717-$ 9721.

23. Becker-Andre, M. and K. Hahlbrock. 1989. Absolute mRNA quantification using the polymerase chain reaction (PCR). An novel approach by a PCR aided transcript titration assay. Nucleic Acids Res. 17: 9437-9446.

24. Virdi, A.S., S. Krishna, and B.C. Sykes. 1992. Tandem competitive polymerase chain reaction (TC-PCR): A method for determining ratios of RNA and DNA templates. Mol. Cell. Probes 6: 375-380.

Received July 14, 1994; accepted in revised form September 19, 1994. 


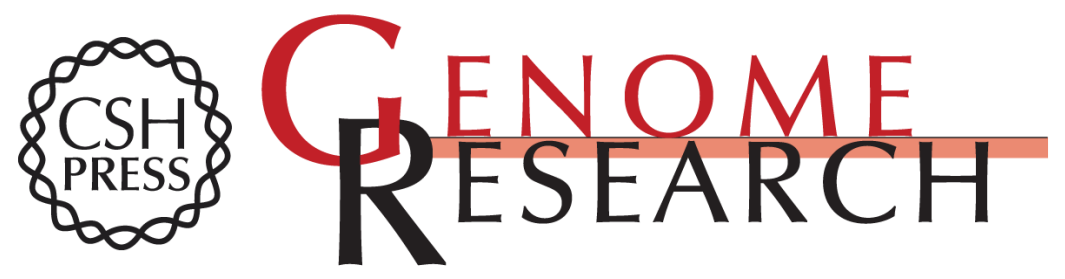

\section{Direct gene quantitation by PCR reveals differential accumulation of ectopic enzyme in rat-1 cells, v-fos transformants, and revertants.}

M B Bahramian and $\mathrm{H}$ Zarbl

Genome Res. 1994 4: 145-153

References This article cites 22 articles, 7 of which can be accessed free at: http://genome.cshlp.org/content/4/3/145.full.html\#ref-list-1

\section{License}

Email Alerting Service

Receive free email alerts when new articles cite this article - sign up in the box at the top right corner of the article or click here.

\section{Affordable, Accurate Sequencing.}

